\title{
Rock fragments with dark coatings in slope deposits of the Famenne region, southern Belgium
}

Gesteentefragmenten met een donkere patina in hellingsafzettingen van de Famenne, Zuid-Belgie

Dirk Goossens, Florias Mees, Eric Van Ranst, Pieter Tack, Laszlo Vincze and Jean Poesen

\section{(2) OpenEdition}

\section{Journals}

Electronic version

URL: http://journals.openedition.org/belgeo/17625

DOI: $10.4000 /$ belgeo. 17625

ISSN: 2294-9135

\section{Publisher:}

National Committee of Geography of Belgium, Société Royale Belge de Géographie

\section{Electronic reference}

Dirk Goossens, Florias Mees, Eric Van Ranst, Pieter Tack, Laszlo Vincze and Jean Poesen, « Rock fragments with dark coatings in slope deposits of the Famenne region, southern Belgium », Belgeo [Online], 4 | 2015, Online since 30 December 2015, connection on 19 April 2019. URL : http:// journals.openedition.org/belgeo/17625; DOI : 10.4000/belgeo.17625

This text was automatically generated on 19 April 2019

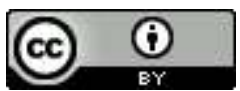

Belgeo est mis à disposition selon les termes de la licence Creative Commons Attribution 4.0 International. 


\section{Rock fragments with dark coatings in slope deposits of the Famenne region, southern Belgium}

Gesteentefragmenten met een donkere patina in hellingsafzettingen van de

Famenne, Zuid-België

Dirk Goossens, Florias Mees, Eric Van Ranst, Pieter Tack, Laszlo Vincze and Jean Poesen

\section{Introduction}

1 Rock varnish is a dark coating found on rocks. It is often observed in deserts where it is also known as desert varnish, but its occurrence is not restricted to arid environments. Rock varnish appears as a thin (from about $1 \mu \mathrm{m}$ to several hundreds of $\mu \mathrm{m}$ ) coloured coating on exposed rock surfaces (Goldsmith et al., 2012). It is mainly composed of clay minerals and amorphous silica (about 70\%) and Mn and Fe oxides (about 30\%) (Dorn, 2007a; Garvie et al., 2008). The formation mechanism of rock varnish is still uncertain although abiotic chemical precipitation, biologically mediated precipitation, or a combination of these two mechanisms, have been proposed (see reviews by Dorn, 2007b and Goldsmith et al., 2012). The current view is that the precipitation and accumulation of atmospheric dust may be an important factor in the formation of rock varnish (Garvie et al., 2008; Hodge et al., 2005), as a source of inorganic and organic constituents.

2 Not all dark rock coatings are rock varnish. True rock varnish is characterized by clay minerals that impose a layered structure to the varnish as seen in cross sections at high magnification (Krinsley, 1998; Krinsley et al., 1995, 2012). Dark coatings that lack clay minerals, and hence a layered cross-sectional structure, are defined as heavy-metal skins (Dorn, 1998; Krinsley et al., 2012). 
Black Mn-rich coatings have been described for a wide variety of environments, including fluvial (Bhatt and Bhat, 1980; Hem and Lind, 1994; Tebo et al., 2005), alpine (Dorn and Oberlander, 1982; Krinsley et al., 2009), arctic (Washburn, 1969) and antarctic settings (Dorn et al., 1992). They have also been reported for cold springs (Hunt, 1972; Mustoe, 1981) and in hot springs (Tazaki, 2000); in caves (Northup et al., 2010; Rossi et al., 2010), in fractures within regolith and bedrock (Kim et al., 2006), and as cutans in soils (Huang et al., 2011). A comprehensive overview is given by Krinsley et al. (2012). The use of rock coatings as a paleoenvironment indicator has therefore been criticized (Garvie et al., 2008; Goldsmith et al., 2012).

4 Manganese-rich coatings on stream gravels are fairly common and have been described for various parts of the world, especially North America (Carpenter et al., 1975; Huelin et al., 2006; Krinsley et al., 2012; Whitney, 1981). In contrast to desert environments, where the rate of true varnish formation is in the order of only a few micrometers per millennium (Dorn, 1998; Liu and Broecker, 2000), rocks regularly exposed to water may become coated within decades or even only a few years (Krinsley et al., 2012).

The present study reports the occurrence of rock fragments with a well-developed dark coating in Quaternary slope deposits which, according to Alexandre and Macar (1960), occur within an abandoned meander bend of the Lesse river in Belgium. The dark, almost black precipitation of mainly manganese and iron oxides is well developed, typically on the upper side of the fragments whereas the other side is much less affected, similar to typical rock varnish (figure 1). The coating may have formed in either an arid or a fluvial environment. Previous studies (Demoulin, 1990; Alexandre and Thorez, 1995) have reported indications, such as silicification, for a rather arid climate in this region in the late Neogene. Since then, the climate has significantly cooled down.

This study investigates the chemical, mineralogical and petrographical composition of the coating using incident light microscopy, transmitted light polarization microscopy, Xray diffraction (XRD) analysis, energy dispersive spectrometry (EDS), and X-ray fluorescence (XRF) microspectroscopy. XRD analyses were also performed for the sediment matrix in which the coated rock fragments are embedded, both for bulk samples and for material that was separated in suspension. The aim is to determine whether the coating formed as rock varnish or as a heavy-metal skin, and to reconstruct the origin of the Fe and $\mathrm{Mn}$ in the coating. 
Figure 1. Rock fragments from the Wanlin site with typical dark patina.

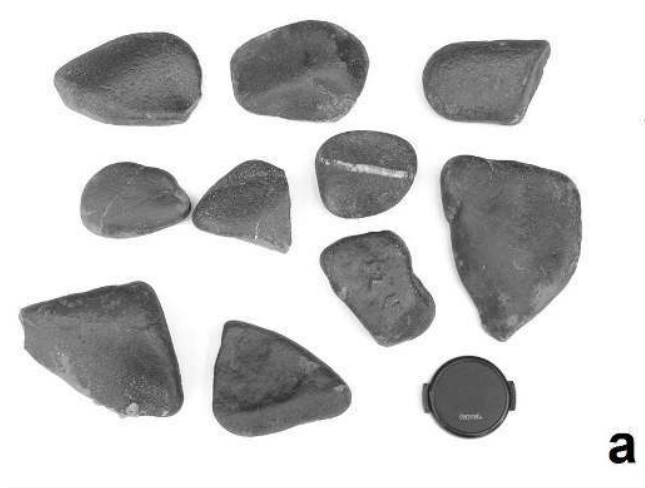

a

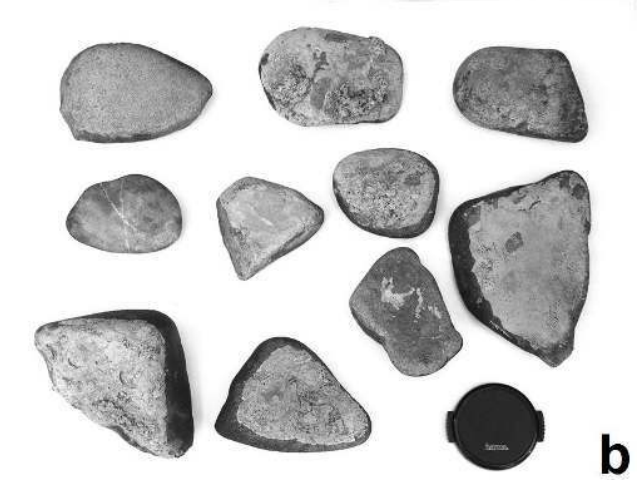

(A) TOP SIDE (WITH WELL-DEVELOPED COATINg) ; (B) BOTTOM SIDE (WITHOUT COATINg). LENS CAP (5 CM DIAMETER) FOR SCALE.

\section{Geomorphic and climatic settings}

7 The study site is located in Wanlin (5008'50" N, 504'17" E; $140 \mathrm{~m}$ asl), $45 \mathrm{~km}$ SE of Namur (figure 2). The coated rock fragments occur in slope deposits in an abandoned meander bend of the Lesse river. Near Wanlin the Lesse flows within a large depression (Famenne depression) and its valley is cut into shales of Famennian age (late Devonian). The sampling site is located on a partly infilled meander with fluvial and colluvial deposits of Quaternary age. These deposits contain rounded sandstone fragments embedded in weathered angular shale fragments, described by Alexandre and Macar (1960) and Juvigné (1979) as grèzes litées. This is a special type of slope deposit consisting of sandy and gravelly material produced by frost shattering (mode $2.5 \mathrm{~mm}$, maximum size $25 \mathrm{~mm}$; see Ozouf et al., 1995). 
Figure 2. Location of Wanlin site.

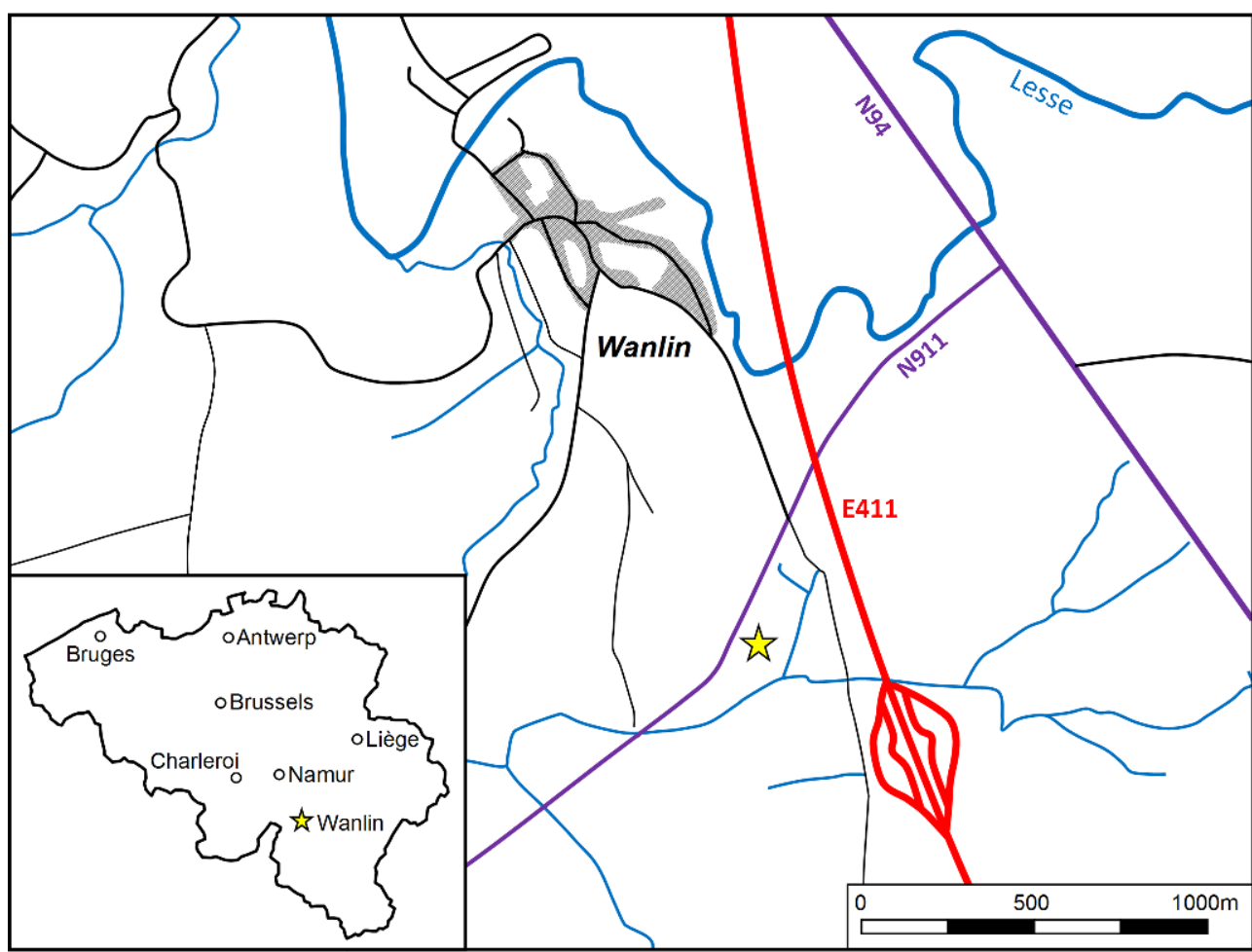

SAMPLING SITE OF THE INVESTIGATED ROCK FRAgMENTS (INDICATED BY YELLOW STAR): $50^{\circ} 08^{\prime} \mathbf{5 0 "} \mathrm{N}$ AND $5^{\circ} 04^{\prime} 16^{\prime \prime}$ E, AT A DEPTH OF 1-2 M BELOW THE SURFACE (142 M ASL).

8 in outcrops some $20 \mathrm{~km}$ south of Wanlin. They were subsequently transported by the Lesse, deposited in terraces, and then reworked with the local shales in slope deposits.

9

In a nearby quarry where weathered shale fragments are extracted for brick making, a detailed stratigraphic description of the channel infillings has been reported by Juvigné (1979). The deposits are up to $11 \mathrm{~m}$ thick and include a buried soil profile at a depth of ca. $6 \mathrm{~m}$.

The current climate is a temperate maritime climate with a mean annual air temperature of ca. $10^{\circ} \mathrm{C}$ and a mean annual precipitation of ca. $850 \mathrm{~mm}$. 
Figure 3. View of Wanlin site.

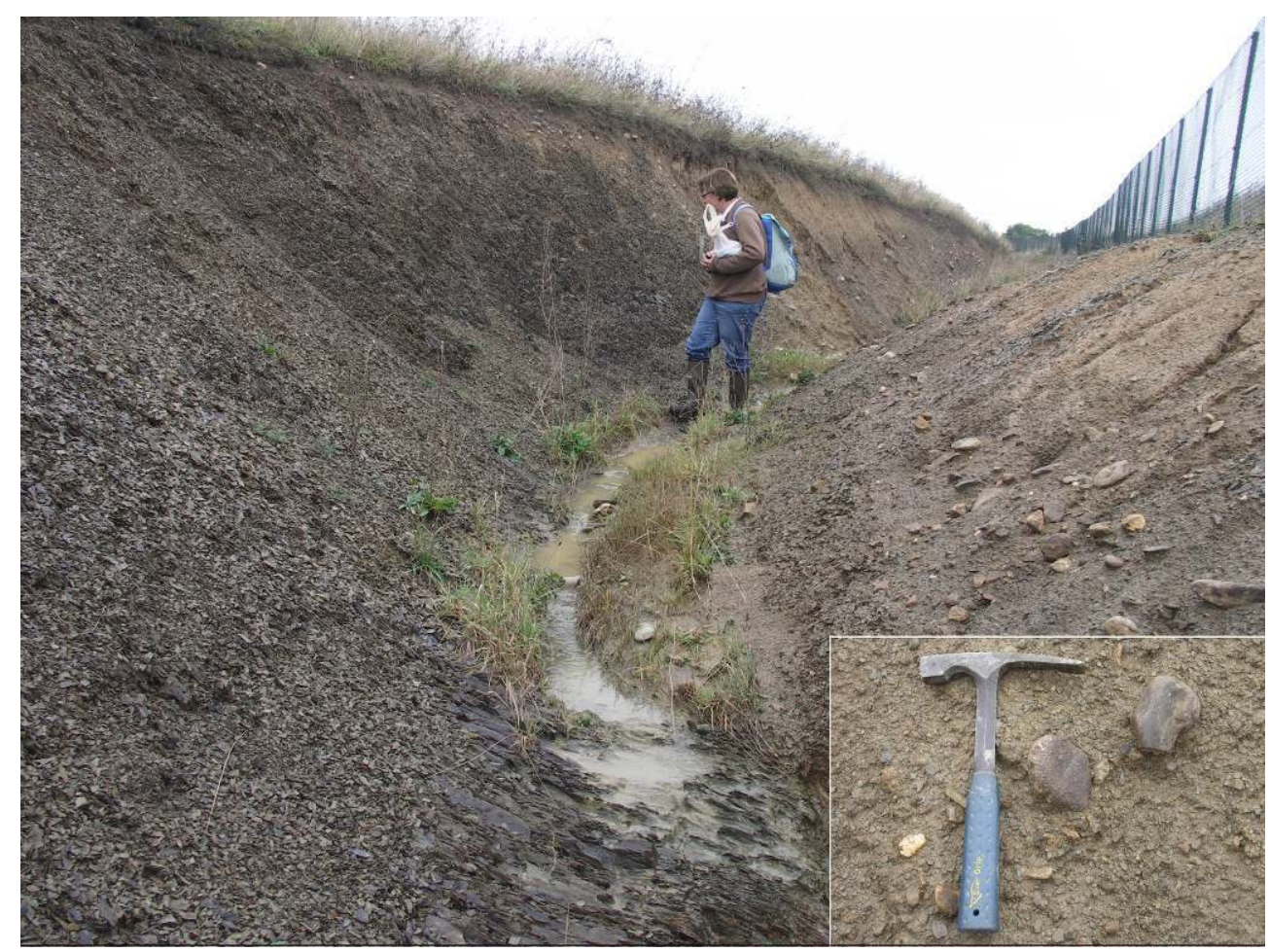

The Famennian shales occur left of the ditch. The deposit right of the ditch is the grèze litée in which the coated sandstones are embedded. Inset shows coated fragments in situ. Diameter of the two large fragments in inset photo is approximately $10 \mathrm{~cm}$.

\section{Methods}

Representative sandstone fragments with well-developed coatings were collected from the Wanlin site for analysis. Size of the sampled fragments was 5 to $10 \mathrm{~cm}$. Morphological features of the coatings were studied in transversal cross sections for polished surfaces (incident light microscopy) and in thin sections (transmitted light polarization microscopy). X-ray diffraction (XRD) analysis was performed for thin slabs, cut parallel to the coated surface, that were placed as such in the sample holder of the equipment used (Philips X'pert System; $\mathrm{CuK}_{\alpha}, 3-70^{\circ} 2 \theta, 0.02^{\circ} 2 \theta$ step size, $1 \mathrm{sec} / \mathrm{step}$ ). For the same series of subsamples, the chemical composition of the coatings was verified using an energy dispersive spectrometry system (Noran Vantage), coupled to a Jeol JSM-6400 scanning electron microscope (SEM-EDS). For both XRD and SEM-EDS analysis, the underside of the slabs was analyzed as a reference, representative of the interior of the rock fragments.

XRD analyses were also performed for the sediment in which the sandstone fragments occur, both for bulk samples and for material that was separated in suspension, the latter with and without glycol treatment. Dithionite-citrate-bicarbonate (DCB)-extractable Fe and Mn contents were determined (method of Mehra and Jackson, 1960) for samples of the local shale bedrock, selecting fragments with and without dark staining.

14 X-ray fluorescence (XRF) spectroscopy measurements were performed using a micro-XRF system (Eagle-III microprobe, EDAX, Inc.) providing information on elemental composition and distribution for atomic numbers $Z>10$. The Eagle-III XRF microprobe is 
equipped with a microfocus Rh-anode X-ray tube, a polycapillary lens (X-ray Optical Systems, Inc.), and a $80-\mathrm{mm}^{2}$ energy dispersive $\mathrm{Si}(\mathrm{Li})$ detector. An X-ray tube voltage of 40 $\mathrm{kV}$ and filament current of $125 \mu \mathrm{A}$ were applied. Two rock fragments ("Famenne A" and "Famenne B") were each analyzed in two different regions of $300 \mu \mathrm{m} \times 200 \mu \mathrm{m}$ using a 25$\mu \mathrm{m}$ beam spot size and 5 - $\mu \mathrm{m}$ step size under vacuum conditions. The live measurement time was set to $25 \mathrm{~s}$ per point. XRF spectra were fitted using the AXIL software package (Vekemans et al., 1994).

\section{Results}

\section{Textural features}

The coated rock fragments from Wanlin are coarse-grained sandstones, with only minor amounts of fine material. Polished cross sections and thin sections show that the coatings are thin surface deposits of dark fine material, typically with a prominent associated zone in which the sandstone substrate is impregnated by the same material (up to a few mm thick) (figure 4). In some rock fragments, impregnation occurs in a band that is separated from the surface by an unaffected interval (see figure $4 \mathrm{~b}$ ).

Figure 4. Micromorphology of the coatings on sandstone fragments from the Wanlin site.
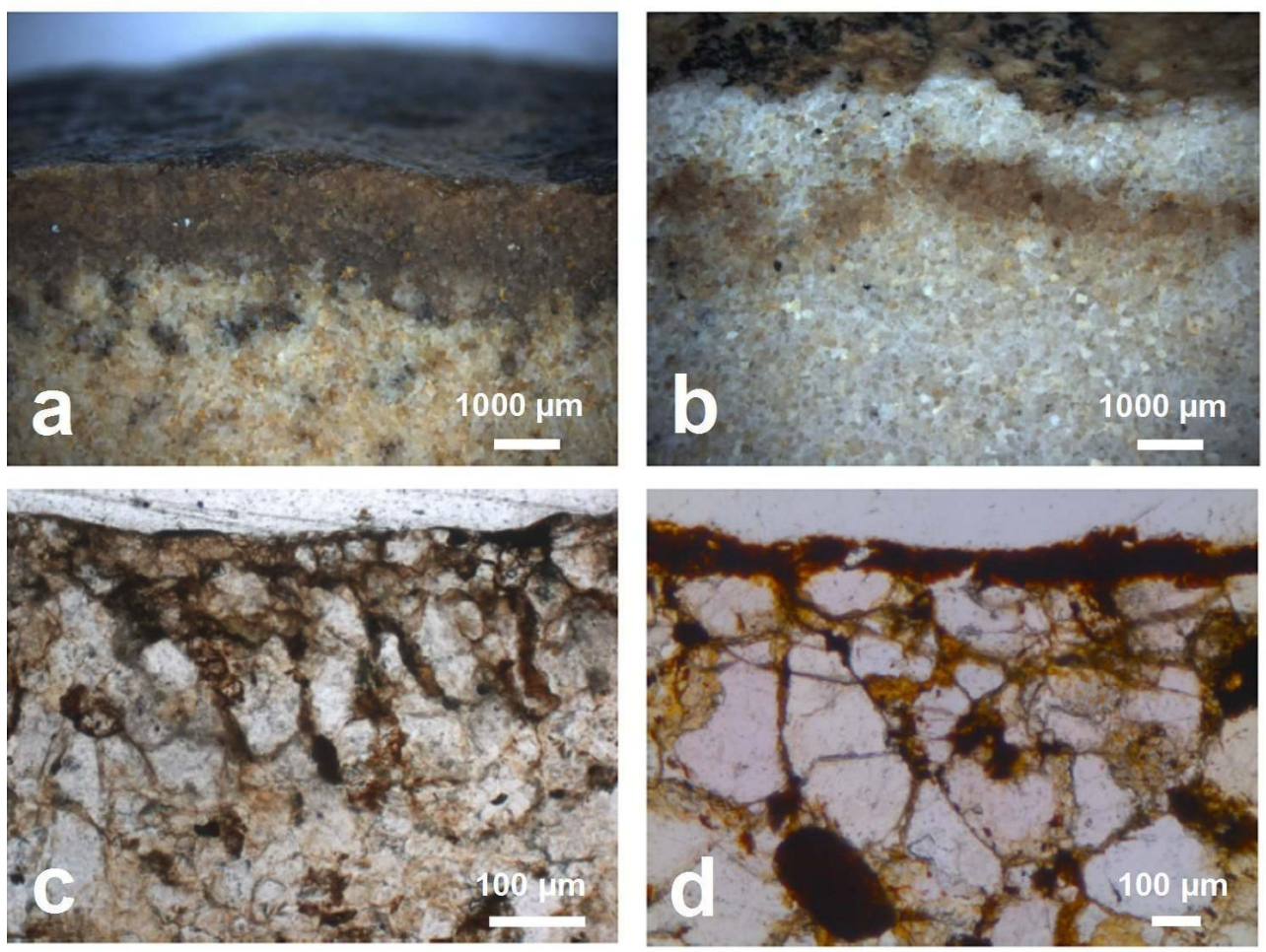

(A) DARK COATINg WITH ADJACENT THICK INTERVAL WITH STRONg IMPREgNATION BY THE SAME MATERIAL (POLISHED SURFACE); (B) BAND WITH MODERATE IMPREgNATION THAT IS SEPARATED FROM THE SURFACE OF THE ROCK FRAgMENT (POLISHED SURFACE); (C) THIN COATINg OF DARK fINE MATERIAL, AND PENETRATION OF THE SAME MATERIAL ALONg GRAIN BOUNDARIES IN THE NEIgHBOURINg PART OF THE SUBSTRATE (THIN SECTION); (D) PROMINENT COATINg COVERINg THE SURFACE, WITH SUBORDINATE ASSOCIATED IMPREgNATIVE OCCURRENCE OF THE SAME MATERIAL (THIN SECTION). 


\section{Chemical composition}

16 SEM-EDS analysis (figure 5) demonstrates that the coatings have a high iron and manganese content ( $\sim 18 \mathrm{wt} \% \mathrm{MnO}_{2}, \sim 7 \mathrm{wt} \% \mathrm{Fe}_{2} \mathrm{O}_{3}$, diluted by substrate contribution). Comparison with the interior of the sandstone fragments shows that the coatings also have a much higher concentration of $\mathrm{Al}, \mathrm{Mg}, \mathrm{K}$ and Ca relative to the amount of Si.

Figure 5. SEM-EDS spectra for coatings and the covered substrate, for a representative fragment from the study site.

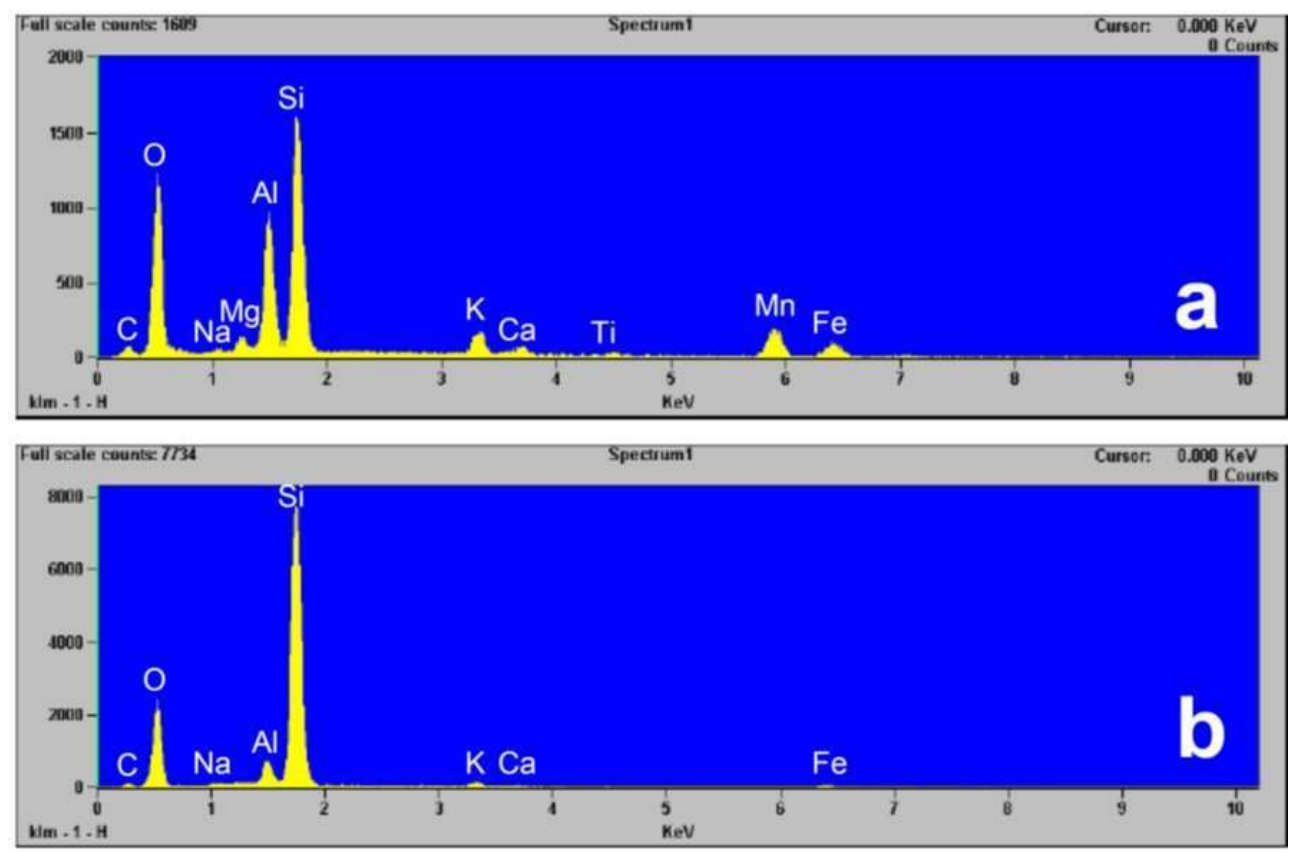

(A) COATINg; (B) SUBSTRATE.

17 The shale substrate occurring in outcrops near the Wanlin site has a low DCB-extractable $\mathrm{Mn}$ and $\mathrm{Fe}$ content $\left(0.01 \% \mathrm{MnO}_{2}, 1.62 \% \mathrm{Fe}_{2} \mathrm{O}_{3}\right)$. In parts with dark staining, the DCBextractable manganese content is significantly higher, to a greater extent than the iron content $\left(0.25 \% \mathrm{MnO}_{2}, 2.06 \% \mathrm{Fe}_{2} \mathrm{O}_{3}\right)$.

XRF imaging shows the presence of $\mathrm{Al}, \mathrm{Si}, \mathrm{K}, \mathrm{Ti}, \mathrm{Mn}$ and $\mathrm{Fe}$, together with minor $\mathrm{S}$ and $\mathrm{Ni}$, in the coatings. $\mathrm{Mn}, \mathrm{Fe}, \mathrm{Al}$ and $\mathrm{K}$ distribution images are shown in figures 6 and 7. In all mapped regions, the coating is clearly enriched in $\mathrm{Mn}$, with associated $\mathrm{Fe}$, and it is also marked by a relatively high content in $\mathrm{Al}, \mathrm{Si}$ and $\mathrm{K}$. Within the mapped regions, $\mathrm{Fe}$ content is also high in parts beneath the surface, largely without associated high Mn-Al$\mathrm{K}$. These parts correspond to brownish Fe-oxide deposits occurring along grain boundaries between the sand grains that constitute the substrate.

\section{Mineralogical composition}

19 XRD analysis of the coated side of analyzed slabs shows that no crystalline Fe or Mn oxide minerals are present. The XRD patterns also reveal a difference in composition of the clay fraction, which consists of mica and smectite in the coatings and only of smectite in the substrate. The substrate also has a lower clay mineral content than the coatings. 
20 The sediment matrix enclosing the sandstone fragments has a bulk composition dominated by calcite and quartz, and it contains smectite, chlorite and muscovite as clay minerals. For the analyzed suspension, only chlorite and muscovite were detected as clay minerals.

\section{Discussion}

The coatings that characterize the sandstone fragments in the Wanlin slope deposits are essentially $\mathrm{Fe} / \mathrm{Mn}$ oxide features, developed as surface deposits with characteristic associated impregnation of the substrate. The presence of an intervening interval without impregnation records a more complex evolution, with depletion of the outer part of an impregnated zone that developed at an earlier stage. Both types of impregnative features are common in soils affected by oxido-reduction processes resulting in iron oxide redistribution (see Lindbo et al., 2010). The local shale bedrock is a likely Mn source, but high Mn contents could not be confirmed, based on analyses that do record high Mn mobility and whose results may be affected by Mn redistribution, whereby the analyzed fragment without staining may have been depleted.

XRD analysis demonstrates that the Fe/Mn compounds are amorphous or at least poorly crystalline. It also reveals differences in the abundance and nature of clay minerals between the coatings and the substrate, in agreement with SEM-EDS results. This feature is compatible with incorporation of fine material that is part of the sediment matrix during coating development. However, if muscovite contained in the coatings is derived from this source, the lack of chlorite needs to be explained. A possible reason is a difference in grain size between clay mineral species, whereby chlorite, as usual, is the coarsest phase (see Van Ranst et al., 1982) and therefore more likely to be displaced rather than incorporated during accretionary coating development.

Clay incorporation is confirmed by XRF mapping, with matching patterns for Mn-Fe and also for Al-Si-K. The element maps also show that this characteristic is largely confined to the coatings, whereby seemingly associated occurrences at subsurface levels have a different composition, without associated $\mathrm{Al}$ and $\mathrm{K}$.

The dark coatings on the Wanlin sandstone fragments formed by precipitation of Mn and Fe supplied by water, and not by atmospheric deposition. The source of Mn is most probably the local shale bedrock, despite relatively low measured Mn concentrations. Mn and Fe oxides in the coatings did not originate from the sampled sandstone fragments themselves. The coatings are rich in clay, which has most probably been incorporated during $\mathrm{Mn} / \mathrm{Fe}$ oxide accumulation, although some differences in composition between coating and matrix are as yet unexplained. By invoking oxido-reduction processes, a local Mn source, and matrix incorporation, coating development is implied to result from percolating groundwater after burial. Coatings can develop on gravel and boulders in river beds (see Krinsley et al., 2012), but no contribution of Mn and Fe supplied by the local Lesse river is assumed for the Wanlin occurrence. The percolation concept explains the unique occurrence of the coatings on one side (the upper part) of the rock fragments. Preferential prevalence of oxidizing conditions along the top of the rock fragments could have enhanced the process. The possibility that the coatings had already formed in the original river terrace is unlikely because in that case the orientation of the coatings in the slope deposits would have been much more random, which is not what we see in the field. 
Figure 6. XRF element maps for $\mathrm{Mn}-\mathrm{Ka}$, Fe-Ka, Al-Ka and $\mathrm{K}-\mathrm{Ka}$, for the areas marked by the rectangle in the thin-section photograph (left).

(Rock sample: Famenne A)
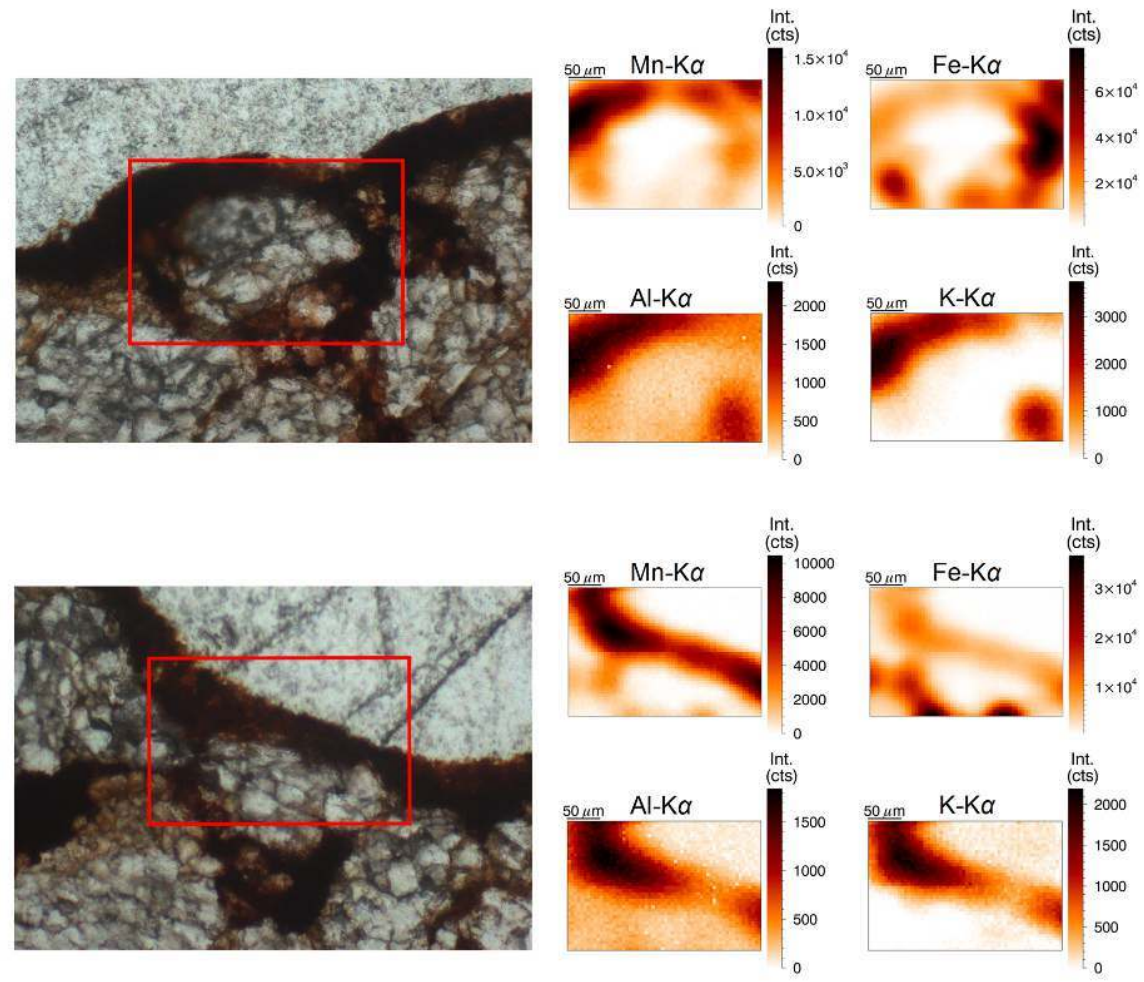

Figure 7. XRF element maps for $\mathrm{Mn}-\mathrm{Ka}$, Fe-Ka, Al-Ka and $\mathrm{K}-\mathrm{Ka}$, for the areas marked by the rectangle in the thin-section photograph (left). 

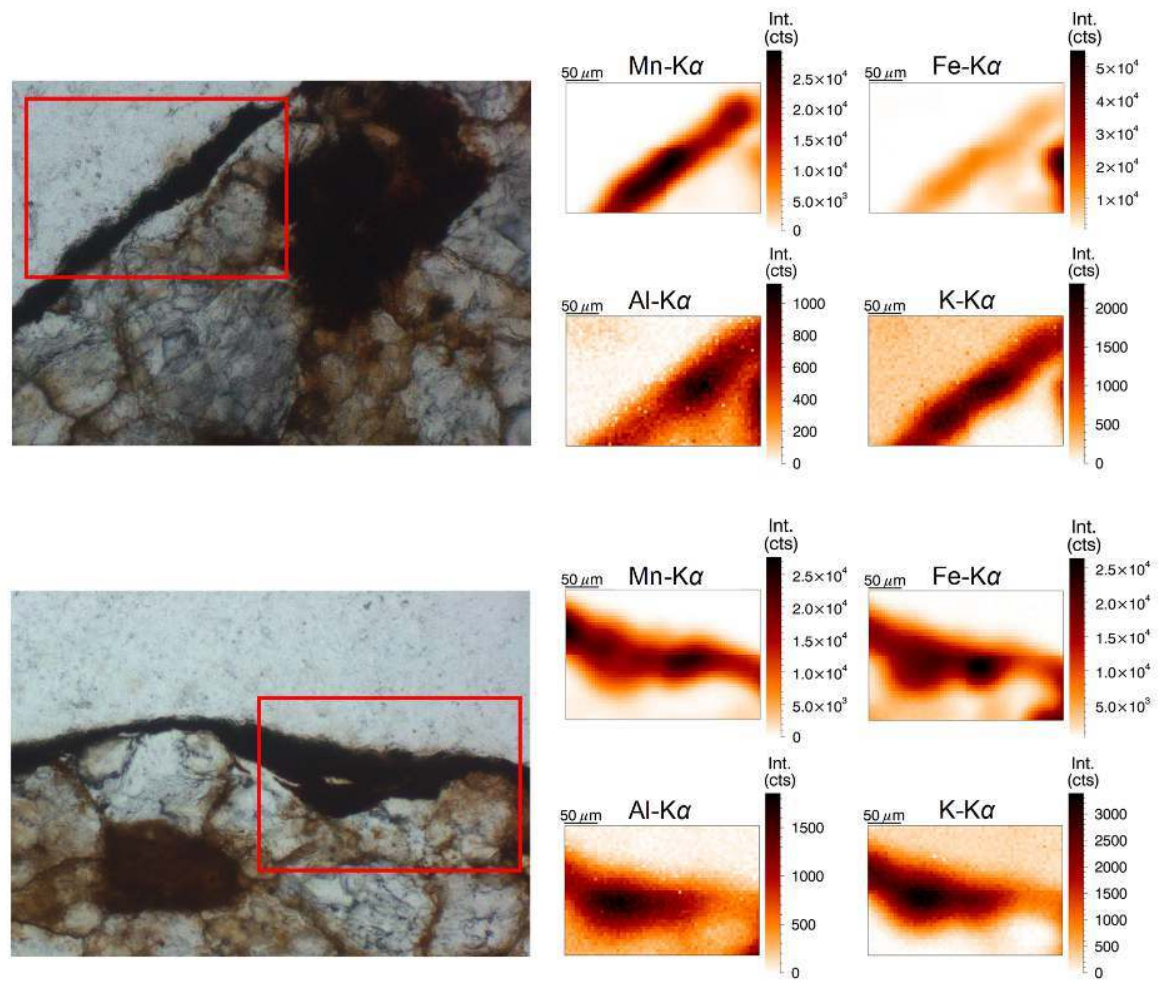

Because of their strong macroscopic resemblance with coatings that are formed as typical rock varnish, the $\mathrm{Mn} / \mathrm{Fe}$ oxide coatings in the slope deposits at Wanlin could easily be misinterpreted as rock varnish. The analyses performed show that they are most likely heavy-metal skins.

\section{Conclusions}

The dark coatings on the sandstone fragments in the grèzes litées at Wanlin are Fe/Mn oxide deposits, formed in conditions with high mobility of those compounds. A possible local source of manganese and associated iron is recognized in the form of Mn-containing Palaeozoic shales, as observed in a quarry near the sampling site. The incorporation of matrix material along the surface of the sandstone fragments, and especially the impregnative nature of part of the $\mathrm{Fe} / \mathrm{Mn}$ oxides, are significant criteria that can be applied in studies of subsurface occurrences of rock fragments with possible rock vanish. 


\section{BIBLIOGRAPHY}

ALEXANDRE J. \& MACAR P. (1960), "Excursion du jeudi 11 juin 1959, Liège -Baraque Fraiture Rochefort - Liège. Le périglaciaire préwurmien", Les Congrès et Colloques de l'Université de Liège, 17, pp. 187-197.

ALEXANDRE J. \& THOREZ J. (1995), “Au secondaire et au Tertiaire, l'Ardenne Tropicale. L'altération des roches et les climats anciens”, in DEMOULIN A. \& PISSART A. (eds.), L'Ardenne. Essai de géographie physique, Liège, Département de Géographie Physique et Quaternaire, Université de Liège, pp. 53-67.

BHATT M.V. \& BHAT G.A. (1980), "On the deposition of manganese and other metal compounds on the stones in river beds", Current Science, 49, pp. 23-24.

CARPENTER R.H., POPE T.A. \& SMITH R.L. (1975), “Fe-Mn coatings in stream sediment geochemical surveys", Journal of Geochemical Exploration, 4, pp. 349-363.

DEMOULIN A. (1990), "Les silicifications tertiaires de la bordure nord de L'Ardenne et du Limbourg méridional (Europe NO)”, Zeitschrift für Geomorphologie, 34, pp. 179-197.

DORN R.I. (1998), Rock Coatings, Amsterdam, Elsevier.

DORN R.I. (2007a), "Baking black opal in the desert sun: the importance of silica in desert varnish: comment and reply", Geology, 35, pp. 122-123.

DORN R.I. (2007b), “Rock varnish.”, in NASH D.J. \& MCLAREN S.J. (eds.), Geochemical Sediments and Landscapes, Oxford, Blackwell, pp. 246-297.

DORN R.I., KRINSLEY D.H., LIU T., ANDERSON S., CLARK J., CAHILL T.A. \& GILL T.E. (1992), "Manganese-rich rock varnish does occur in Antarctica", Chemical Geology, 99, pp. 289-298.

DORN R.I. \& OBERLANDER T.M. (1982), “Rock varnish”, Progress in Physical Geography, 6, pp. 317-367.

GARVIE L.A.J., BURT D.M. \& BUSECK P.R. (2008), "Nanometer-scale complexity, growth, and diagenesis in desert varnish", Geology, 36, pp. 215-218.

GOLDSMITH Y., ENZEL Y. \& STEIN M. (2012), “Systematic Mn fluctuations in laminated rock varnish developed on coeval early Holocene flint artifacts along a climatic transect, Negev desert, Israel", Quaternary Research, 78, pp. 474-485.

HEM J.D. \& LIND C.J. (1994), “Chemistry of manganese precipitation in Pinal Creek, Arizona, USA: a laboratory study", Geochimica et Cosmochimica Acta, 58, pp. 1601-1613.

HODGE V.F., FARMER D.E., DIAZ T. \& ORNDORFF R.L. (2005), "Prompt detection of alpha particles from ${ }^{210} \mathrm{Po}$ : another clue to the origin of rock varnish?", Journal of Environmental Radioactivity, 78, pp. 331-342.

HUANG L., LIU F., WANG M.K. \& TAN W. (2011), "Factors influencing elemental distribution in iron-manganese cutans of three subtropical soils”, Soil Science, 176, pp. 48-56.

HUELIN S.R., LONGERICH H.P., WILTON D.H.C. \& FRYER B.J. (2006), “The determination of trace elements in Fe-Mn oxide coatings on pebbles using LA-ICP-MS", Journal of Geochemical Exploration, 91, pp. 110-124. 
HUNT C.B. (1972), Geology of Soils, San Francisco, Freeman.

JUVIGNE E. (1979), “Etude stratigraphique des dépôts du méandre recoupé de la Lesse à Wanlin (Famenne)", Bulletin de la Société Géographique de Liège, 15, pp. 65-75.

KIM J.G., LEE G.H., LEE J., CHON C., KIM T.H. \& HA K. (2006), “Infiltration pattern in a regolithfractured bedrock profile: field observations of a dye stain pattern", Hydrological Processes, 20, pp. 241-250.

KRINSLEY D. (1998), "Models of rock varnish formation constrained by high resolution transmission electron microscopy”, Sedimentology, 45, pp. 711-725.

KRINSLEY D.H., DORN R.I. \& TOVEY N.K. (1995), “Nanometer-scale layering in rock varnish: implications for genesis and paleoenvironmental interpretation", Journal of Geology, 103, pp. 106-113.

KRINSLEY, D., DORN R.I. \& DIGREGORIO B.E. (2009), “Astrobiological implications of rock varnish in Tibet", Astrobiology, 9, pp. 551-562.

KRINSLEY D.H., DORN R.I., DIGREGORIO B.E., LANGWORTHY K.A. \& DITTO J. (2012), “Rock varnish in New York: An accelerated snapshot of accretionary processes", Geomorphology, 138, pp. 339-351.

LINDBO D.L., STOLT M.H. \& VEPRASKAS M.J. (2010), “Redoximorphic features”, in STOOPS G., MARCELINO V. \& MEES F. (eds), Interpretation of Micromorphological Features of Soils and Regoliths, Amsterdam, Elsevier, pp. 129-147.

LIU T. \& BROECKER W.S. (2000), “How fast does rock varnish grow?”, Geology, 28, pp. 183-186.

MEHRA D. \& JACKSON M. (1960), "Iron oxides removed from soils and clays by a dithionite citrate buffered with sodium bicarbonate”, Clays and Clay Minerals, 7, pp. 317-327.

MUSTOE G.E. (1981), "Bacterial oxidation of manganese and iron in a modern cold spring”, Geological Society of America Bulletin, 92, pp. 147-153.

NORTHUP D.E., SNIDER J.R., SPILDE M.N., PORTER M.L., VAN DE KAMP J.L., BOSTON P.J., NYBERG A.M. \& BARGAR J.R. (2010), "Diversity of rock varnish bacterial communities from Black Canyon, New Mexico”, Journal of Geophysical Research, 115, G02007.

OZOUF J.-C., COUTARD J.-P. \& LAUTRIDOU J.-P. (1995), “Grèzes, grèzes litées: Historique des définitions", Permafrost and Periglacial Processes, 6, pp. 85-87.

ROSSI C., LOZANO R.P., ISANTA N. \& HELLSTROM J. (2010), “Manganese stromatolites in caves: El Soplao (Cantabria, Spain)", Geology, 38, pp. 1119-1122.

TAZAKI K. (2000), “Formation of banded iron-manganese structures by natural microbial communities", Clays and Clay Minerals, 48, pp. 511-520.

TEBO B.M., JOHNSON H.A., MCCARTHY J.K. \& TEMPLETON A.S. (2005), “Geomicrobiology of manganese (II) oxidation", Trends in Microbiology, 13, pp. 421-428.

VAN RANST E., DE CONINCK F., TAVERNIER R. \& LANGOHR R. (1982), “Mineralogy in silty to loamy soils of Central and High Belgium in respect to autochthonous and allochthonous materials", Bulletin de la Société Belge de Géologie, 91, pp. 27-44.

VEKEMANS B., JANSSENS K., VINCZE L., ADAMS F. \& VANESPEN P. (1994), “Analysis of X-ray spectra by iterative least squares (AXIL): New developments”, X-Ray Spectrometry, 23, pp. 278-285. WASHBURN A.L. (1969), “Desert varnish.”, in WASHBURN A.L. (ed.), Weathering, Frost Action and Patterned Ground in the Mesters District, Northeast Greenland, Kopenhagen, Reitzels, pp. 14-15. 
WHITNEY P.R. (1981), "Heavy metals and manganese oxides in the Genesee Watershed, New York State: effects of geology and land use", Journal of Geochemical Exploration, 14, pp. 95-117.

\section{ABSTRACTS}

Quaternary slope deposits near the Lesse river in the Famenne region, south Belgium, contain scattered rounded rock fragments (5-15 cm diameter) that are typically characterized by a dark coating or patina. This dark surface resembles rock varnish occurrences. To establish the nature of the coatings, chemical, mineralogical and petrographical analyses were performed. The coatings are essentially $\mathrm{Fe} / \mathrm{Mn}$ oxide features, developed as surface deposits on the rock fragments with associated impregnation of the rock substrate. The Fe/Mn compounds are amorphous or at least poorly crystalline. The coating also shows enrichment in clay minerals compared to the matrix of the covered rock fragments. Some of these characteristics are typical for rock varnish, but the coating does not show a layered structure. We hypothesize that the coating was formed by precipitation of $\mathrm{Mn}$ and Fe supplied by water, after burial of the rock fragments in the surrounding slope deposits, and was not affected by atmospheric deposition. Despite its strong macroscopic resemblance to rock varnish the patina on the Famenne rocks must most likely be classified as a heavy-metal skin.

In quartaire hellingsafzettingen nabij de Lesse komen afgeronde keien (5-15 cm diameter) voor met een donkere patina aan het oppervlak. De patina doet sterk denken aan woestijnlak. Chemisch, mineralogisch en petrografisch onderzoek toont aan dat de patina voornamelijk bestaat uit een toplaag van Fe/Mn-oxide met gedeeltelijke impregnatie van het gesteente. De Fe/ Mn-verbindingen zijn amorf of hoogstens zwak kristallijn. De patina vertoont ook een aanrijking met kleimineralen vergeleken met de steenmatrix rond de keien zelf. Woestijnlak vertoont dezelfde kenmerken, maar de patina op de Famennestenen mist een gelaagde structuur. Het lijkt erop dat de patina gevormd werd door neerslag van door water aangevoerd ijzer en mangaan, en niet door atmosferische neerslag. Ondanks de sterke macroscopische gelijkenis met woestijnlak lijkt het erop dat de patina moet beschouwd worden als een zgn. metal skin: een aanrijking, zonder gelaagde structuur, van metalen op gesteente.

\section{INDEX}

Keywords: rock coating, varnish, slope deposits, Famenne

motsclesnl patina, keien, hellingsafzettingen

\section{AUTHORS}

\section{DIRK GOOSSENS}

Division of Geography and Tourism, KU Leuven Department of Earth and Environmental Sciences, Celestijnenlaan 200E, 3001 Leuven, Belgium, Dirk.Goossens@ees.kuleuven.be

\section{FLORIAS MEES}

Department of Geology and Mineralogy, Royal Museum for Central Africa, Leuvensesteenweg 13, 3080 Tervuren, Belgium, florias.mees@africamuseum.be 


\section{ERIC VAN RANST}

Department of Geology and Soil Science (WE13), Ghent University, Krijgslaan 281 (S8), 9000 Gent, Belgium, Eric.VanRanst@UGent.be

\section{PIETER TACK}

Department of Analytical Chemistry, Ghent University, Krijgslaan 281 (S12), 9000 Gent, Belgium, Pieter.Tack@UGent.be

\section{LASZLO VINCZE}

Department of Analytical Chemistry, Ghent University, Krijgslaan 281 (S12), 9000 Gent, Belgium, Laszlo.Vincze@UGent.be

\section{JEAN POESEN}

Division of Geography and Tourism, KU Leuven Department of Earth and Environmental Sciences, Celestijnenlaan 200E, 3001 Leuven, Belgium, Jean.Poesen@ees.kuleuven.be 